\title{
VITAL CHARACTERS OF PROJECT-COOPERATORS DRIVING THE SUCCESS OF CACAO PLANTATION ESTABLISHMENT IN BUKIDNON, PHILIPPINES
}

\author{
Vences C. Valleser ${ }^{*}$, Josephine L. Arbes ${ }^{2}$, Andrew B. Melencion ${ }^{1}$, Karen \\ Debbie J. Cosrojas ${ }^{3}$, Glenn R. Dayondon ${ }^{4}$ \\ ${ }^{1}$ Department of Horticulture, College of Agriculture, Central Mindanao University, Philippines \\ ${ }^{2}$ Department of Agricultural Education and Extension, College of Agriculture, Central Mindanao University, \\ Philippines \\ ${ }^{3}$ Department of Agricultural Economics, College of Agriculture, Central Mindanao University, Philippines \\ ${ }^{4}$ Department of Biology, College of Arts and Sciences, Central Mindanao University, Philippines \\ *corresponding author: vcvalleser@gmail.com
}

\begin{abstract}
One way to realize the targeted 100 thousand metric tons of dried cocoa beans by the Philippines on year 2022 is the massive establishment of new cacao plantations. With the financial support through the grant-in-aid program of the Philippine Council for Agriculture, Aquatic and Natural Resources, Research and Development, Central Mindanao University reached-out to neighboring communities and helped the people in Bukidnon, Philippines to establish new cacao plantations using the high-yielding clones recommended by the National Seed Industry Council. A total of 39 project-cooperators were involved and were provided with farm inputs as well as seminars and trainings on cacao production through the "Science and Technology Community-Based Farm (STCBF) for a Sustainable Cacao Production in Bukidnon" project. However, it cannot be denied that characters of project-cooperators have great influence on the performance of cacao plantation. This study was undertaken to determine the influence of prior learnings (previous seminars and trainings on cacao production), regularity of farm visit, involvement in farm handson activities and level of technology adoption of project-cooperators on the performance of established cacao plantation. Characters of project-cooperators with regard to farm management were documented during the farm monitoring and evaluation conducted by our team. Results revealed that project-cooperators who visited their farm regularly have better cacao plantation performance than those of project-cooperators who visited their farm occasionally. Apparently, cacao plantation performed better if project-cooperators were highly receptive to transferred technology. These findings can be used as guide to agricultural extension workers in Bukidnon, Philippines in the selection of project-cooperators or project beneficiaries with regard to establishment of cacao plantations.
\end{abstract}

Keywords: Cacao farmer; cocoa plantation; farm management; farm monitoring; technology adoption.

http://dx.doi.org/10.21776/ub.agrise.2020.020.3.8

Received 26 May 2020

Accepted 30 June 2020

Available online 29 July 2020

\section{INTRODUCTION}

The huge market demand along with persistent favorable prices made cacao as a priority crop in the Philippines nowadays. Global consumption of cocoa per capita currently reaches $0.59 \mathrm{~kg}$, with an estimated annual increase by $4 \%$ (Izaati, Anindita,
\& Sujarwo, 2020). In the Philippines, production volume of cacao from 2014-2018 was increasing linearly (Figure 1). However, this volume is still inferior compared to the targeted 100,000 MT of dried beans by 2022 (Department of Agriculture [DA], 2017). In order to improve cacao productivity in the country, establishment of new cacao

CITATION: Valleser, V., C., Arbes, J., L., Melencion, A., B., Cosrojas, K., D., J., Dayondon, G., R. (2020). Vital Characters of Project-Cooperators Driving the Success of Cacao Plantation Establishment in Bukidnon, Philippines, Agricultural Socio-Economics Journal, 20(3), 245-252 DOI: http://dx.doi.org/10.21776/ub.agrise.2020.020.3.8 
plantations using the high-yielding clones recommended by the National Seed Industry Council (NSIC) is of great advantage. The active involvement of local farmers is very much needed to materialize this approach. But, it is also important to consider the sociodemographic profile of farmers as this factor affects the performance of cacao plantation.

In our previous study, we found out that land tenure status of project-cooperators significantly influenced the establishment of new cacao plantations (Valleser, Dayondon, Arbes, Melencion, \& Cosrojas, 2020) in Bukidnon, Philippines. Though we have provided the project-cooperators with seminars and trainings related to cacao production, we have not considered the previous cacao production trainings (aside from the trainings we provided them) attended by each projectcooperator. In Cameroon, agricultural training strongly affects and correlates with food crop production (Tambi, 2019). Moreover, Ahmad, Jadoon, Ahmad and Khan (2007) reported that there was an increase in crop yield and an upward trend in vegetables and fruit crops production in Mansehra district as a result of agricultural training.

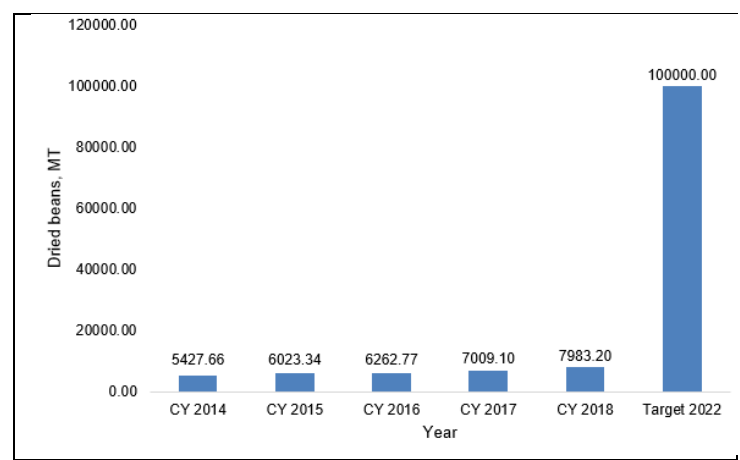

Figure 1. Volume of cocoa dried bean production in the Philippines from 2014-2018; adopted from Valleser et al. (2020)

Aside from training or prior learnings, characters of farmers might also affect the performance of cacao plantation. Tarabla and Dood (1990) reported that farmer's personal and social characteristics affects milk yield and quality of dairy animals. Also, it cannot be denied that farms located adjacent to farmer's household is easy to manage than those distant farms. Kassali, Ayanwale and Williams (2009) reported that farm distance from the farmers' place of residence affects the farmers' technical efficiency in Oke-ogun area of Oyo State, Nigeria. Inevitably, farm distance could be one of the reasons why some farmers are hesitant to visit their farms in a regular basis. Relative to this, farmer's consistency to visit the farm could be an essential factor influencing the farm's performance. In effect, level of technology adoption could also be affected.

This study evaluated the influence of projectcooperators' prior learnings (trainings), and characters (regularity of farm visit, involvement in farm hands-on activities and level of technology adoption) on the establishment of cacao plantation in Bukidnon, Philippines.

\section{RESEARCH METHODS}

\section{Study Implementation}

This study was conducted at the two municipalities (Lantapan and Maramag) and two cities (Malaybalay and Valencia) of Bukidnon province in the Philippines on August 2016 to July 2019. This study was part of our outputs in the PCAARRD funded project titled "Science and Technology Community-Based Farm (STCBF) for a Sustainable Cacao Production in Bukidnon".

With the help of local government unit (LGU) representatives from the collaborating municipality/city, 39 project-cooperators were identified and selected. The 39 project-cooperators involved in this project were distributed as follows: nine from Lantapan, 10 from Maramag, 15 from Malaybalay City, and five project-cooperators came from Valencia City.

\section{Establishment of Cacao Plantations}

We provided various seminars and trainings to project-cooperators from 2016-2019 which were relevant to cacao production. Then, CMU provided agricultural inputs (planting materials and fertilizers) for them to establish new cacao plantations. We also provided them technical assistance during the establishment phase of cacao plantation.

\section{Monitoring and Evaluation}

We monitored and evaluated the performance of each established cacao plantation regularly. Projectcooperators' characters were also monitored and documented. We rated the performance of each cacao plantation established using 1-7 (1- poor; 3satisfactory; 5- very good; and 7- outstanding) hedonal rating scale previously used by Valleser et al. (2020). For the purpose of this study, we consider only the performance of cacao plantation during the completion of STCBF for a Sustainable Cacao Production in Bukidnon project as influenced by project-cooperators' characters. Performance rating of cacao plantation was mainly based on 1) growth 
of cacao with reference to cacao plants at CMU's high-yielding varieties (HYV) of cacao clonal garden for a particular stage of growth, 2) plant mortality, 3) pests and diseases damaged, and 4) degree of field sanitation (Valleser et al., 2020).

\section{Data Gathered and Statistical Analysis}

Project-cooperators' prior learnings and characters (regularity of farm visit, involvement in farm handson activities and level of technology adoption) were evaluated in composite manner regardless of municipality/city. We used t-test in the statistical analysis of data. So, each project-cooperators' prior learnings and characters were grouped into two.

Project-cooperators were categorized as (1) with prior learnings and (2) without prior learnings (Table 1). These prior learnings include all the previous seminars/trainings related to cacao production attended by project-cooperator before they join the STCBF for a Sustainable Cacao Production in Bukidnon project.

In terms of regulariy of farm visit, the two categories of project-cooperators were: (1) regular and (2) occasional (Table 1). Farmers who visted their farms at least three times per week were categorized under the 'regular'. Whereas, farmers who visted their farms at less than three times per week were considered as 'occassional'.

For the involvement in farm hands-on activities, we grouped the project-cooperators as (1) with involvement and (2) without involvement (Table 1). Farm hands-on activities include all activities from land preparation to harvesting. Those project-cooperators belonging to without involvement in farm hands-on activities relied mainly on paid laborers to maintain their cacao plantations.

In terms of level of adoption to technology transferred, we grouped the project-cooperators as (1) $>50 \%$ and $(2) \leq 50 \%$ (Table 1). In this study, we transferred two technologies such as intercropping with annual/perennial crops and water impounding or provision of irrigation.

\section{RESULTS AND DISCUSSION}

Project-Cooperators' Prior Learnings on the Performance of Cacao Plantation

Prior learnings gained through seminars, trainings and workshops could improve the farm decisionmaking of farmers. Agricultural trainings have a positive impact on agricultural productivity (Tambi, 2019; Ahmad et al., 2007). However, in our study, prior learnings of project-cooperators (aside from the seminars and trainings we provided them) before joining the project seem to have no positive effects on the establishment of cacao plantation (Figure 2). Performance of cacao plantations established by project-cooperators with or without prior learnings or trainings on cacao production were statistically comparable. This result also confirms the positive impact of the seminars/trainings as well as the recommendations (based on our farm monitoring and evaluation visits) we provided to projectcooperators during the project implementation on the success of cacao plantation establishment.

\section{Regularity of Farm Visit by Project-Cooperators on the Performance of Cacao Plantation}

Cacao is a perennial tree crop. As observed in the province, cacao farmers does not devote regular weekly visit to their farms considering that the crop will start to produce pods after two years from field transplanting. During the vegetative growth of cacao, cultural management practices such as manual weeding, fertilizer application, and pruning can be employed at monthly interval. Hence, there's no need to conduct regular weekly monitoring. But, our study revealed that cacao plantations managed by project-cooperators who visited their farms regularly (at least thrice a week) performed better than those established plantations by projectcooperators who only visited their farms occasionally (Figure 3).

Cacao farming therefore is intensive. Though most of the cultural management practices can be employed at monthly interval, devoting regular time in the farm has an advantage. Farmers could plan for possible measures on recurring problems especially pests and diseases in the farm. Most of the projectcooperators residing adjacent to their farms were the one's who conducted regular weekly visits. Whereas, those project-cooperators with farms in distant locations conducted only occasional monitoring. According to Kassali et al. (2009), farm distance from the farmers' place of residence affects the farmers' technical efficiency in Oke-ogun area of Oyo State, Nigeria. Thus, having a projectcooperators residing near the farm would be an advantage in the establishment of cacao plantation. This will allow project-cooperators to effectively monitor their farms leading to a successful cacao plantation establishment. 
Table 1. Characteristics of project-cooperators

\begin{tabular}{|c|c|c|c|c|c|}
\hline 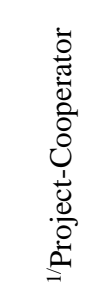 & 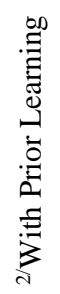 & 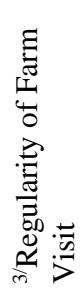 & 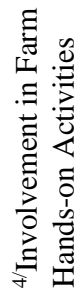 & 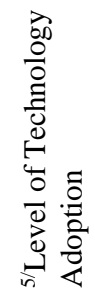 & 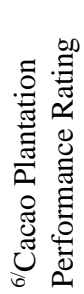 \\
\hline LN-1 & $\mathrm{N}$ & $\mathrm{R}$ & $\mathrm{Y}$ & $>50 \%$ & 7.00 \\
\hline LN-2 & $\mathrm{N}$ & $\mathrm{R}$ & $\mathrm{Y}$ & $>50 \%$ & 3.00 \\
\hline LN-3 & $\mathrm{N}$ & $\mathrm{R}$ & $\mathrm{Y}$ & $>50 \%$ & 3.00 \\
\hline LN-4 & $\mathrm{N}$ & $\mathrm{R}$ & $\mathrm{Y}$ & $>50 \%$ & 7.00 \\
\hline LN-5 & $\mathrm{N}$ & $\mathrm{O}$ & $\mathrm{Y}$ & $\leq 50 \%$ & 3.00 \\
\hline LN-6 & $\mathrm{N}$ & $\mathrm{R}$ & $\mathrm{Y}$ & $>50 \%$ & 5.00 \\
\hline LN-7 & $\mathrm{N}$ & $\mathrm{R}$ & $\mathrm{N}$ & $\leq 50 \%$ & 1.00 \\
\hline LN-8 & $\mathrm{N}$ & $\mathrm{O}$ & $\mathrm{Y}$ & $\leq 50 \%$ & 1.00 \\
\hline LN-9 & $\mathrm{N}$ & $\mathrm{O}$ & $\mathrm{Y}$ & $\leq 50 \%$ & 1.00 \\
\hline MC-1 & $\mathrm{N}$ & $\mathrm{R}$ & $\mathrm{Y}$ & $>50 \%$ & 7.00 \\
\hline MC-2 & $\mathrm{Y}$ & $\mathrm{R}$ & $\mathrm{Y}$ & $>50 \%$ & 5.00 \\
\hline MC-3 & $\mathrm{N}$ & $\mathrm{R}$ & $\mathrm{N}$ & $>50 \%$ & 5.00 \\
\hline MC-4 & $\mathrm{N}$ & $\mathrm{R}$ & $\mathrm{N}$ & $>50 \%$ & 3.00 \\
\hline MC-5 & $\mathrm{N}$ & $\mathrm{R}$ & $\mathrm{Y}$ & $>50 \%$ & 3.00 \\
\hline MC-6 & $\mathrm{N}$ & $\mathrm{R}$ & $\mathrm{N}$ & $>50 \%$ & 3.00 \\
\hline MC-7 & $\mathrm{Y}$ & $\mathrm{O}$ & $\mathrm{Y}$ & $\leq 50 \%$ & 1.00 \\
\hline MC-8 & $\mathrm{N}$ & $\mathrm{R}$ & $\mathrm{Y}$ & $>50 \%$ & 5.00 \\
\hline MC-9 & $\mathrm{N}$ & $\mathrm{R}$ & $\mathrm{Y}$ & $>50 \%$ & 3.00 \\
\hline MC-10 & $\mathrm{N}$ & $\mathrm{R}$ & $\mathrm{Y}$ & $>50 \%$ & 3.00 \\
\hline MC-11 & $\mathrm{N}$ & $\mathrm{R}$ & $\mathrm{Y}$ & $>50 \%$ & 3.00 \\
\hline MC-12 & $\mathrm{N}$ & $\mathrm{R}$ & $\mathrm{Y}$ & $>50 \%$ & 5.00 \\
\hline MC-13 & $\mathrm{N}$ & $\mathrm{R}$ & $\mathrm{Y}$ & $\leq 50 \%$ & 1.00 \\
\hline MC-14 & $\mathrm{Y}$ & $\mathrm{O}$ & $\mathrm{N}$ & $>50 \%$ & 5.00 \\
\hline MC-15 & $\mathrm{N}$ & $\mathrm{R}$ & $\mathrm{Y}$ & $\leq 50 \%$ & 1.00 \\
\hline VC-1 & $\mathrm{N}$ & $\mathrm{O}$ & $\mathrm{N}$ & $\leq 50 \%$ & 1.00 \\
\hline VC-2 & $\mathrm{N}$ & $\mathrm{R}$ & $\mathrm{Y}$ & $>50 \%$ & 5.00 \\
\hline VC-3 & $\mathrm{N}$ & $\mathrm{R}$ & $\mathrm{Y}$ & $>50 \%$ & 3.00 \\
\hline VC-4 & $\mathrm{N}$ & $\mathrm{R}$ & $\mathrm{Y}$ & $>50 \%$ & 5.00 \\
\hline VC-5 & $\mathrm{N}$ & $\mathrm{O}$ & $\mathrm{Y}$ & $\leq 50 \%$ & 1.00 \\
\hline MR-1 & $\mathrm{N}$ & $\mathrm{R}$ & $\mathrm{Y}$ & $>50 \%$ & 5.00 \\
\hline MR-2 & $\mathrm{N}$ & $\mathrm{R}$ & $\mathrm{Y}$ & $>50 \%$ & 7.00 \\
\hline MR-3 & $\mathrm{N}$ & $\mathrm{O}$ & $\mathrm{Y}$ & $>50 \%$ & 3.00 \\
\hline MR-4 & $\mathrm{N}$ & $\mathrm{O}$ & $\mathrm{Y}$ & $\leq 50 \%$ & 1.00 \\
\hline MR-5 & $\mathrm{N}$ & $\mathrm{O}$ & $\mathrm{Y}$ & $\leq 50 \%$ & 1.00 \\
\hline MR-6 & $\mathrm{N}$ & $\mathrm{O}$ & $\mathrm{Y}$ & $\leq 50 \%$ & 1.00 \\
\hline MR-7 & $\mathrm{N}$ & $\mathrm{O}$ & $\mathrm{Y}$ & $\leq 50 \%$ & 1.00 \\
\hline MR-8 & $\mathrm{Y}$ & $\mathrm{R}$ & $\mathrm{Y}$ & $>50 \%$ & 3.00 \\
\hline MR-9 & $\mathrm{N}$ & $\mathrm{R}$ & $\mathrm{Y}$ & $>50 \%$ & 3.00 \\
\hline MR-10 & $\mathrm{N}$ & $\mathrm{O}$ & $\mathrm{N}$ & $\leq 50 \%$ & 1.00 \\
\hline
\end{tabular}

Legends:

1/ LN- Lantapan; MC- Malaybalay City; VC- Valencia City; MR- Maramag

${ }^{2 /} \&{ }^{4 /}$ Y- Yes; N- No

${ }^{3 /} \mathrm{R}$ - regular; O- occasional

5/ $>50 \%$ - more than $50 \%$ technology adoption; $\leq 50 \%-50 \%$ and below technology adoption

6/ 1- poor; 3- satisfactory; 5-very good; 7- outstanding

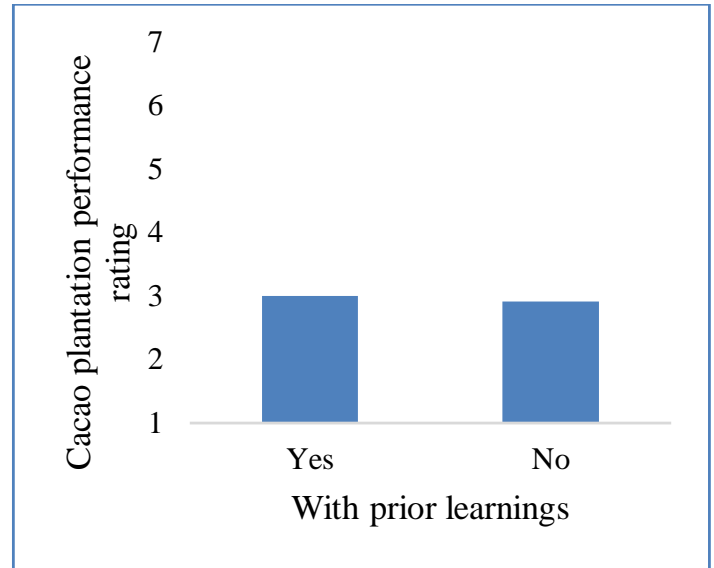

$\mathrm{df}=37 ; \mathrm{t}_{\mathrm{value}}=0.09 ;$ not significant

Figure 2. Performance of cacao plantation established by farmers with prior learnings and without prior learnings

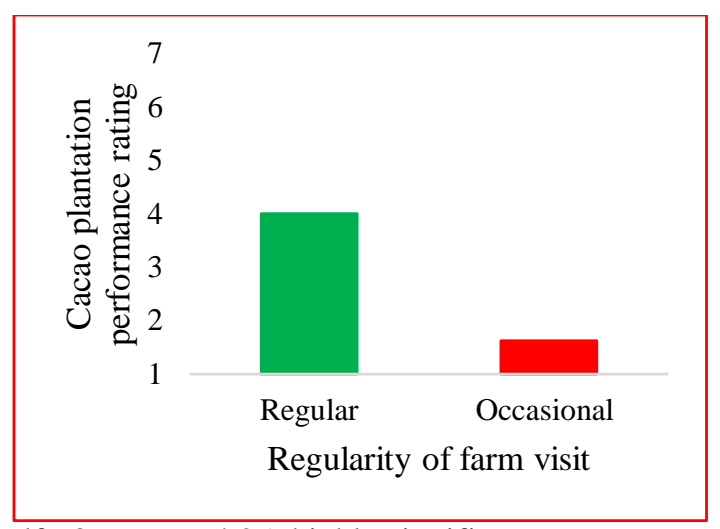

$\mathrm{df}=37 ; \mathrm{t}_{\text {value }}=4.25$; highly significant

Figure 3. Performance of established cacao plantation as influenced by the regularity of farm visit by farmers

\section{Project-Cooperators Involvement in Farm Hands-on Activities on the Performance of Cacao Plantation}

Farm owners can effectively manage their farm if they will be involved in farm hands-on activities from land preparation to postharvest. In this study, there are project-cooperators who are employed and involved in business. In order to effectively manage the establishment of cacao plantation, they hired workers to perform the activities in the farm. But those project-cooperators who relied their income from the farm were the ones who do the cultural management practices. However, $t$-test revealed that involvement of project-cooperators in farm handson activities had no significant impact on the performance of established cacao plantation (Figure 4). Result implies the importance of having a skilled farm worker to do the various cultural management practices in cacao plantation.

The massive establishment of new plantations is one of the potential ways to help revive the Philippine cacao industry. However, it cannot be 
denied that not all Filipinos venturing on cacao production are involved in farm hands-on activities. They are dependent on paid laborers to do the cultural management practices in the farm. Thus, the absence of labor force in cacao production would have negative impact on the performance of cacao plantations and a potential threat in bean yield reduction. In relation, Dar (2019) mentioned that the lack of labor is one of the problems in Philippine agriculture. It is therefore necessary to consider the labor force in the country to effectively manage the newly established cacao plantations. Otherwise, project-cooperators should be the ones to perform the cultural management practices in their respective farms.

\section{Level of Technology Adoption by Project- Cooperators on the Performance of Cacao Plantation}

The presence of irrigation and shade crops are essential on the early vegetative growth of cacao in the field. Hence, these were the basic technologies aside from the use of high-yielding and early bearing cacao clones that we recommended to projectcooperators involved in this study. Yet some projectcooperators wavered certainly because of being laborious and some cacao growers in the province were not employing these basic technologies in their farms. Nonetheless, level of technology adoption had a significant influence on the performance of established cacao plantation (Figure 5). Cacao plantation performed better when projectcooperators embraced the technologies transferred to them (Figures 7-9) compared to the farm of project-cooperator who did not adopt (Figure 10).

Farmer's level of technology adoption affects the performance as well as productivity of the farm (González, Ibarraran, Maffioli, \& Rozo, 2009; Khatur \& Haider, 2016; Tesfaye, Bedada, \& Mesay, 2016). Khatur and Haider (2016) reported that a one percent increase in technology adoption leads to increase in rice productivity by 0.22 percent in Bangladesh. Moreover, Tesyafe et al. (2016) reported that adoption of improved wheat variety increased wheat productivity of adopters by about 1 to $1.1 \mathrm{t} \mathrm{ha}^{-1}$ than the nonadopters in Ethiopia.

Though we did not include the effects of presence of irrigation and shade crops on the establishment phase of cacao plantation, this study emphasized the importance of employing such technologies for the establishment of cacao plantation in Bukidnon, Philippines.

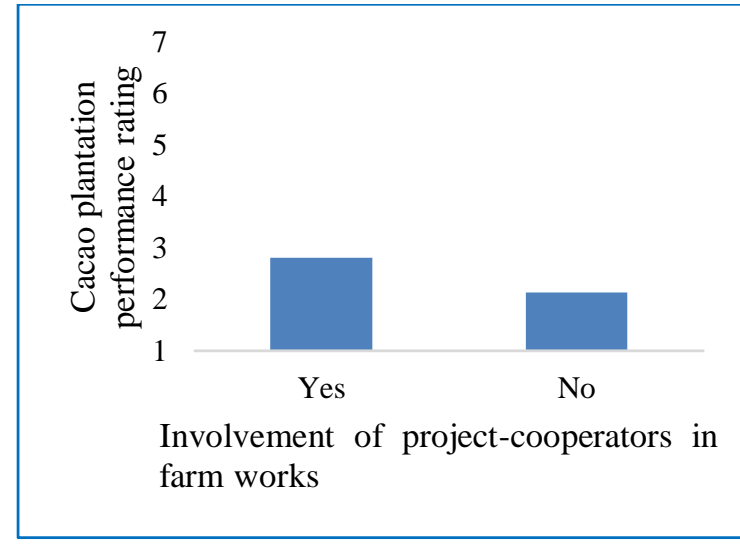

$\mathrm{df}=37 ; \mathrm{t}_{\text {value }}=0.78 ;$ not significant

Figure 4. Performance of cacao plantation established by project-cooperators with involvement and without involvement on farm activities

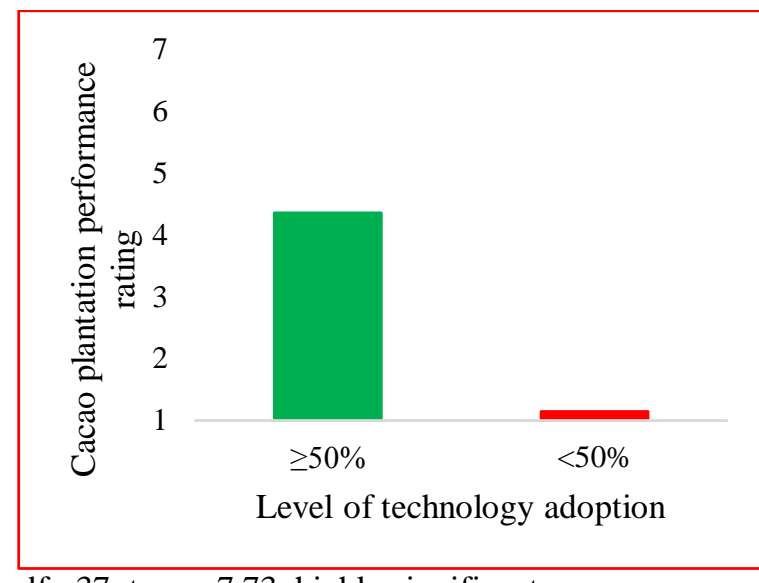

$\mathrm{df}=37 ; \mathrm{t}_{\mathrm{value}}=7.73$; highly significant

Figure 5. Performance of cacao plantation as influenced by the level of technology adoption of project-cooperators

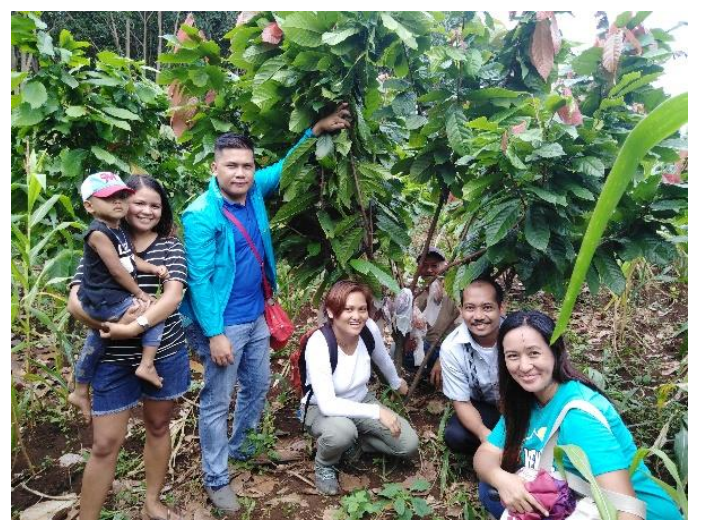

Figure 6. $>50 \%$ level of technology adoption by project-cooperator; pod-bearing two yearold cacao trees in response to corn as shade and small water impoundment as source of water during dry periods at the farm of project-cooperator from Lantapan, Bukidnon 


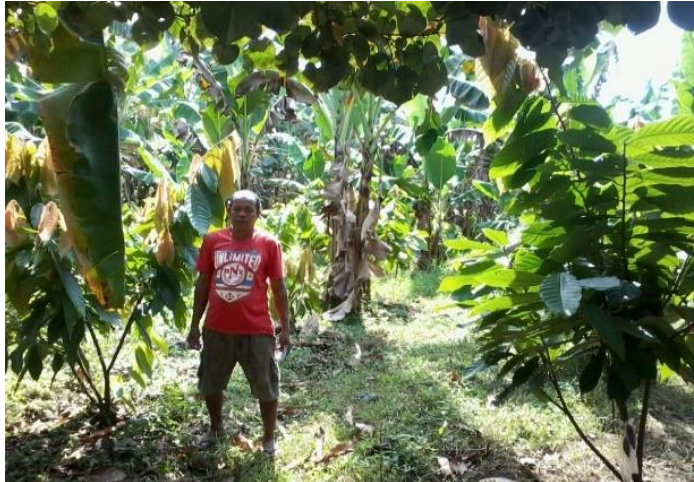

Figure 7. $>50 \%$ level of technology adoption by project-cooperator; vigorous 16 monthold cacao trees in response to banana as shade with the integration of annual vegetables and with source of irrigation at the farm of project-cooperator in Malaybalay City, Bukidnon

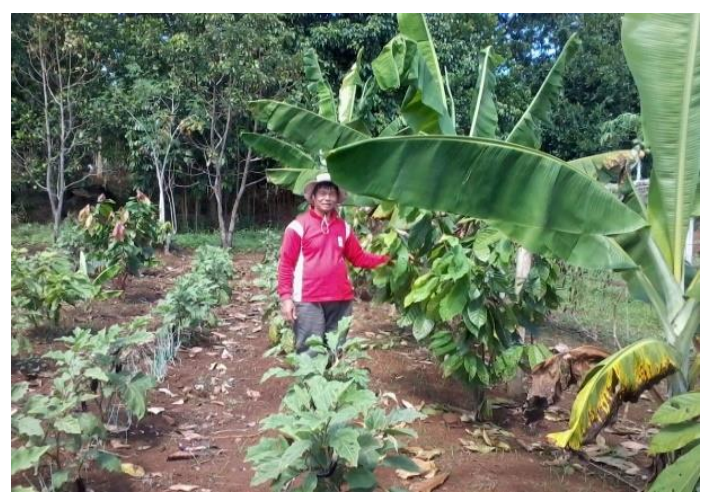

Figure 8. $>50 \%$ level of technology adoption by project-cooperator; vigorous 17 monthold cacao trees in response to banana as shade with the integration of annual vegetables and with source of irrigation at the farm of project-cooperator in Lantapan, Bukidnon

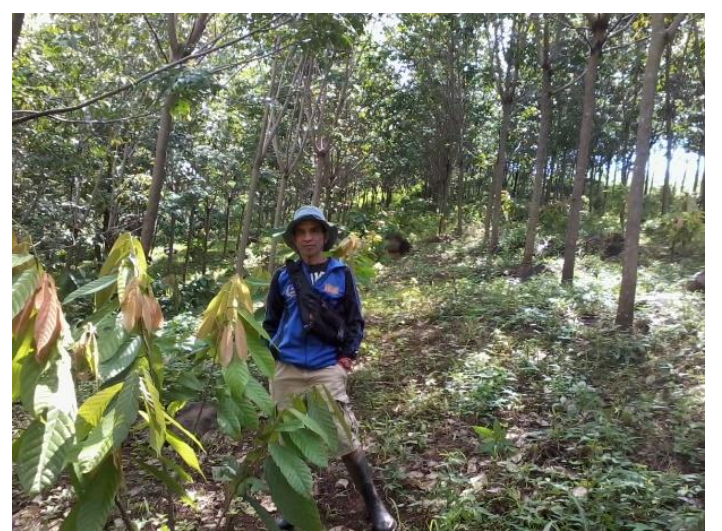

Figure 9. >50\% level of technology adoption by project-cooperator; Vigorous 17 monthold cacao trees in response to rubber as shade and with source of irrigation at the farm of project-cooperator in Maramag, Bukidnon

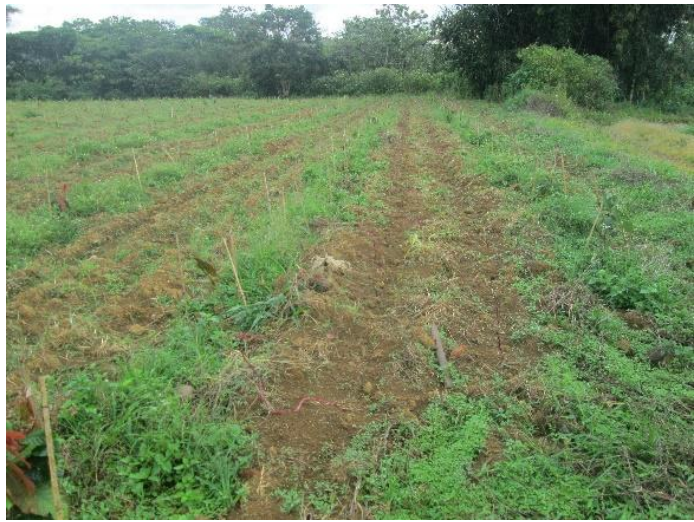

Figure 10. $\leq 50 \%$ level of technology adoption by project-cooperator; high plant mortality and inferior growth of one year-old cacao trees can be observed at the farm of project-cooperator from Lantapan, Bukidnon

\section{CONCLUSION AND RECOMMENDATION}

Regularity of farm visit as well as the level of technology adoption are vital characters of projectcooperators for a successful cacao plantation establishment in Bukidnon, Philippines. Projectcooperators should visit their farm regularly and be receptive to technologies transferred or as recommended by project implementers or the agricultural extension workers. The Philippine government through the local government units therefore needs to consider these traits of farmers as one of the bases in the selection process of projectcooperators with regard to cacao plantation establishment.

\section{ACKNOWLEDGMENT}

The authors wish to thank the Philippine Council for Agriculture and Aquatic Resources Research and Development (PCAARRD) for funding the "Science and Technology Community-Based Farm (STCBF) for a Sustainable Cacao Production in Bukidnon" project. Sincere gratitude is also extended to Central Mindanao University for the administrative support. Local government units of Lantapan, Maramag, Malaybalay City and Valencia City are likewise acknowledged for the significant contributions during the study implementation.

\section{REFERENCES}

Ahmad, M., Jadoon, M. A., Ahmad, I., \& Khan. H. (2007). Impact of trainings imparted to enhance agricultural production in District 
Mansehra. Sarhad Journal of Agriculture, 23(4), 1211-1216.

Dar, W. D. (2019). The 'new thinking' for agriculture. Retrieved March 10, 2020, from http://nmis.gov.ph/index.php/press-releasesmain/405-2019-news-articles/2019-marchnews/1385-the-new-thinking-for-agricultureby-dr-william-d-dar

Department of Agriculture. (2017). 2017-2022 Philippine cacao industry roadmap. Quezon City, Philippines: DA. Retrieved March 2, 2020, from http://bpi.da.gov.ph/bpi/images/PDF_file/Cac ao\%20Industry\%20Roadmap $\% 20 \% 20$ Signed $\% 20 \% 20 \% 20$ March\%2010,\%202017.pdf

González, V., Ibarraran, P., Maffioli, A., \& Rozo, S. (2009). The impact of technology adoption on agricultural productivity: the case of the Dominican Republic. SSRN Electronic Journal. DOI: 10.2139/ssrn.2481447.

Izaati, I. M., Anindita, R., \& Sujarwo. (2020). Analysis of integration and price efficiency: a case of Indonesian cocoa beans export market. Agricultural Socio-Economics Journal, 20(2), 167-178.

http://dx.doi.org/10.21776/ub.agrise.2020.020 .2.9.

Kassali, R., Ayanwale, A. B., \& Williams, S. B. (2009). Farm location and determinants of agricultural productivity in the Oke-ogun area of Oyo State, Nigeria. Journal of Sustainable Development in Africa, 11(2), 1-19. https://www.researchgate.net/publication/242 527765 .
Khatun, M. F., \& Haider, M. Z. (2016). Impact of technology adoption on agricultural productivity. Journal of Agriculture and $\begin{array}{lll}\text { Crops, } & \text { 2(9), } & \text { 87-93. }\end{array}$ http://arpgweb.com/?ic=journal\&journal=14 \&info=aims

Tambi, M. D. (2019). Agricultural training and its impact on food crop production in Cameroon. Journal of Socioeconomics and Development, 2,1-11. DOI: $10.31328 /$ jsed.v2i1.740

Tarabla, H. D., \& Dodd, K. (1990). Associations between farmers' personal characteristics, management practices and farm performance. British Veterinary Journal, 146(2), 157-164.

Tesfaye, S., Bedada, B., \& Mesay, Y. (2016). Impact of improved wheat technology adoption on productivity and income in Ethiopia. African Crop Science Journal, 24, 127-135. DOI: http://dx.doi.org/10.4314/acsj.v24i1.14S

Valleser, V. C., Arbes, J. L., Melencion, A. B., Cosrojas, K. D. J., \& Dayondon, G. R. (2020). Is sociodemographic profile of projectcooperator essential on the success of cacao plantation establishment? Agricultural Socio-Economics Journal, 20(2), 97-106. http://dx.doi.org/10.21776/ub.agrise.2020.020 .2.2. 